\title{
A háromszéki közbiztonság megszilárdítása a HABSBURG neoabszolutizmus időszakában
}

A z 1526-os mohácsi vészt követően Magyarország három részre szakadásával Erdély magyar irányítás alatt álló fejedelemséggé alakult, amely az 1699-es karlócai békét követően a magyar királyi tisztséget betöltő HABSBURGok felügyelete alá került.

A HABSBURG hatalom a Magyar Királyságnak a törököktől visszahódított területén felállította a bécsi udvar érdekeit képviselő és kivitelező - kormányszékeket. A török hódoltság alól felszabadított országrészek adminisztrálása 1724-ben kezdődött meg Pozsonyban, míg a korábbi Erdélyi fejedelemség felett az Erdélyi Udvari Kancellária rendelkezett Nagyszeben székhellyel. A közigazgatás és annak rendvédelmi ügyeit tehát mindkét esetben Bécsben igyekeztek meghatározni, bár a vármegyék védelmezték a hatáskörükbe tartozó rendvédelmet. Erdélyben a hatalom a bécsi udvar által kinevezett katonai föparancsnok kezében összpontosult. ${ }^{1}$

A XVIII. század második felében, kiváltképp Erdély délnyugati részén, a földesúr és a jobbágy kapcsolata folyamatosan romlott. Az előbbit a haszonélvezet kamatoztatása, az utóbbit pedig a magasabb robot megszüntetése késztette ellenállásra.

Erdély délnyugati részein elsősorban a nemességgel szemben alakult ki a jobbágyság lázadása. $\mathrm{E}$ vidéken jelentős részben a magyar nemes és a döntő többségben román jobbágyság volt az etnikai és társadalmi összetétel jellemzője. A nemesekkel szembeni ellentét elsősorban tehát a döntően ortodox hitüekből tört fel, és a magyar natioból származó nemesek személyi és vagyoni javaik károsultak. Példaként szolgál erre, hogy a legtöbb helyen az agresszivitás fényében ortodox hitre kényszerített kereszteltetésekre, vagy ortodox esketési szertartás szerint házasításokra került sor, amelyeknek előkelö keresztény hölgyeket estek áldozatul. ${ }^{2}$

$\mathrm{Az}$ 1784-es események Háromszék vármegye esetében jól tükrözik hogyan nézett ki a korabeli rendvédelem egy olyan vármegyében, ahol közvetetten nem volt jelen a rebellis megmozdulás, mégis felsőbb utasításra és a nemesség aktív szerepével óvintézkedések egész sorát vezették be.

Erdélyben ebben az időszakban a közigazgatást az Erdélyi Királyi Guberniumból irányították, nagyszebeni székhellyel. Közigazgatási alárendeltségében Háromszék vármegye két közigazgatási kerületre osztva - Sepsi és Kézdi - müködött, amelyek alkerületekből álltak. Az alkerületek irányítására szolgabírókat és rendbiztosokat (comisariusok) neveztek ki. ${ }^{3}$

1784. XI. 8-án fökormányszéki rendeletben szólították fel az erdélyi törvényhatóságokat, a tiszteket és helyetteseiket, hogy tartózkodási helyeiket ne hagyják el, továbbá utasították, hogy tartsák megfigyelés alatt a parasztokat, a birtokukban levő fegyvereket békés úton kíséreljék meg összegyüjteni, amelyeket összeírva, megörzésre a városokba kellett küldeniük, míg a forrongás nem enyhült, egyben tiltva a fegyverek és löszerek vásárlásának lehetőségét is. Szigorították a falvakból való ki- és bejárást, éjjeliöröket állítva fel. ${ }^{4}$

Sepsiszentgyörgy alkerületében, a szolgabíró és a kerületi alispán ${ }^{5}$ felvették a kapcsolatot a határőrségi század-parancsnokkal, aki vállalta az éjszakai járörözést, felállítva hat különböző helyen katonai járőr alakulatokat. A szomszédos falvak ki- és bejáratához pedig civil őröket állítottak, akik felhatalmazást kaptak a településre érkezők, illetve az azt elhagyók ellenőrzésére, szükség esetén akár letartóztatással is élhettek. ${ }^{6}$ Akadtak olyan alkerületek, ahol a szolgabírók ,„)a faluk végén levő strázsaházakban ifjú és jó erőben levő falusi lakos strázsákat [állított]《" és megkövetelte a szigorú ellenörzéseket. ${ }^{7}$

A székelyföldi kerületekben a lázongások megelőzésére a falvak lakói közül „tízesekre” lebontva, megfigyelőket állítottak ki. A falvak közbiztonságának megszilárdítása érdekében a központi hatalom elrendelte, hogy „»»a falusi lakosok, ezeknek számához képest öt, hat, tíz, több vagy kevesebb tizedekre felosztassanak, minden tíz vagy legfeljebb tizenöt lakosok közül egy meghitt ember tizedesnek választassék, aki a gyanús emberek házait minden este és minden reggel eljárja, és ha valamelyik a maga házánál nem hált volna, bíráknak hírré tegyék és ha magát nem legitimálhatná, a processuális szolgabírához vagy comisariushoz, amelyik közelebb lészen a bírák kísértessék el és ezek cselekedjenek vele a guberniális rendelés szerint. «" A tizedesek kötelezettsége mellett a megfigyelése alá tartozóknak jelenteniük kellett, amennyiben el kívánták hagyni a falu határát vagy nem otthon szándékoztak aludni, amelyekre jóváhagyást csak a bíró adhatott. ${ }^{9}$ A kiválasztott tizedeseket azzal a kötelezettséggel állították ,tisztségeikbe”, hogy ha valaki a hatáskörükben a fentebb leírt eljárás egyikébe sem tartozva eltűnik, akkor annak a be nem fizetett adóját neki kell kifizetnie. ${ }^{10}$ A társadalmi rétegződésnek köszönhetően és az egymás iránti bizalmatlanságból eredően, a tizedesek munkáját 
nemesekkel ellenőriztették, akik az „inspectáló főinspektor” megnevezéssel tartották megfigyelés alatt a kiválasztottakat. ${ }^{11}$

A sepsiszentgyörgyi alkerület szolgabírója, az alispánnak 1784. XI. 21-én keltezett írása szerint, egyedül a nemesség képezett olyan megbízható közeget, amelynek segítéségével fenntarthatták a közbiztonságot a falvakban és fegyveres készültséget, valamint éjszakai járőrözéseket voltak képesek tartani közvetlen környezetükben. Az elfogott vétkezőket pedig az Állandó Táblának kellett átadatniuk. $^{12}$

Háromszék területén néhány esetben bujtogatásra is sor került. Az elöállítottak többsége ortodox pap volt, akiket miután elfogtak ,„»vasvillás személyek «" kísértek a cellákba.

Habár a jobbágyság sorsának a fokozottabb javításán fáradozó II. József császár, 1784. XII. 13-án statáriális rendeletek sorát küldte szét a HOREA-féle felkelés megszüntetésére, lépését a katonai vezetőség megelőzte. A főhad-parancsnokság két hadoszlopot az Érchegység vidékén felerősödött felkelés helyszínére vezényelt. Ezen alakulatok pedig néhány hét alatt leverték a lázadást. ${ }^{13}$

Erdély nyugati felében lezajlott forrongások fuvallata, elérte Háromszéket is, amely a nemesi réteget, a közigazgatás személyzetét és a katonai vezetőség tagjait egy táborba tudta sorakoztatni. ${ }^{14} \mathrm{Az}$ együttes fellépés és a szigorú védőintézkedések dacára, Háromszéken nem minden esetben sikerült megakadályozni a parasztok véleménynyilvánítását, szolidaritását a néhány vármegyével odébb zajló jobbágyfelkeléssel kapcsolatosan. ${ }^{15}$

A veszély elmúlta után a hatalommal bírók a hagyományos rendvédelmi szervezeti keretek között rendezték soraikat, míg a - francia forradalom nyomán a Buonaparte NAPÓLEON által korszerüsített - csendőrség intézménye meg nem jelent a HABSBURG-birodalomban is.

Franciaországban 1789-ben kitört a forradalom, amelynek eszmeisége a következő évtizedek során eljutott a kontinens legtöbb nemzetéhez. Közép-Kelet Európában a XVIII. század végén, a XIX. század elején, a birodalmakban élő „elnyomott” nemzetek, a francia forradalmat követően kezdtek egyre nagyobb hangsúlyt fordítani nemzeti és nyelvi értékeikre, kiemelve annak szépségeit, erényeit és előnyeit. A kulturális önállóság felfedezésével egyetemben, politikai síkon is törekedtek érvényt szerezni nemzeti létüknek. ${ }^{16}$ Radikális és kevésbé harcias tömörülések emelkedtek ki gomba módra szerte a HABSBURG-birodalom területén is.

A XIX. század során a térség rendvédelmére általánosan jellemző volt, hogy a polgári felfogásnak megfelelö köz- és személyi biztonság megvalósítására alkalmas rendvédelmi szervezetek akkor kezdtek kiépülni.

A napjainkig megmaradt legáltalánosabban ismert közbiztonsági szervezetek Nyugat-Európából származnak. Közülük kiemelendő helyet foglal el a francia „gens d'armes” megnevezés alatt kifejlödött, - a legutóbbi korokban a magyar megfelelője szerint - a csendőrség néven elterjedt leghatékonyabb közbiztonsági szervezet, amely a Magyarország esetében a XIX. század utolsó, a XX. század első évtizedeiben Magyar Királyi Csendőrség elnevezéssel élte „fénykorát”.

Napjaink számos kiváló történésze a XV. században uralkodó VII. Károly francia uralkodóig vezette vissza e testület kiépülését. A testület létrejöttekor a király személyi őrségét, akaratának érvényesítését és végrehajtását szolgálta, ugyanis a francia haderő kötelékében megjelentek a zsoldosok alakulatok, amelyek jelenléte megkívánta a rendfenntartás igényét a katonai körökben is. ${ }^{17}$

A szervezet a XVIII. század végére, amely akkor még a Maréchaussée nevet viselte — maga mögött tudva mintegy hét évszázad eredményeit és tapasztalatait - diadalutat járt be. Fejlödésében jelentős szerepet játszott a központi hatalom által nyújtott állami támogatás. A francia uralkodó a testületet 1778-ban a, királyi csendörség rangra emelve, ,minden más fegyveres testület elé helyezve ezen szervezetet." 18

Buonaparte NAPÓLEON uralkodásának kiépítésekor értelemszerüen támaszkodott a „Maréchaussée tapasztalataira, hagyományaira, mivel az kiválóan illeszkedett a császárság közigazgatási elképzeléseibe, illetve gyakorlatába. Hatékonyságára, tapasztalataira szükség volt a polgári fejlődés biztonsági feltételeinek létrehozásához, illetve fenntartásához. A forradalom nyomán a napóleoni államszerkezet kialakításakor Gendarmerie Nationale néven illeszkedett be a Maréchaussée a polgári francia állam szervezetébe." 19

A sikeres napóleoni expanziós tervek eredményeképpen, a korábban HABSBURG-házhoz tartozó dél-tiroli és lombardiai területek francia fennhatóság alá kerültek. A napoleoni császárság vonzáskörébe került országokban - a francia közigazgatási minta átvételének a részeként — bevezették a csendőrség intézményét. Így került a csendőrség intézménye Lombardiába.

Buonaparte NAPÓLEON bukása után, az 1814-1815 bécsi békét követően Észak-Itália ismét osztrák fennhatóság alá került. A HABSBURG-hatalom pedig a jól müködő csendőr szervezetet nem 
számolta fel, hanem tovább müködtette. A közbiztonsági szolgálatot ellátó csendör testület jelentős mértékben meghatározta elöbb az osztrák örökös tartományok, később pedig a Kárpát-medencei csendőrség jövőjét. A visszacsatolt Lombardia és Dél-Tirol területén összesen 5 1 12 svadrony katonai erő biztosította a közbiztonság ellenőrzését. A Svadronyok mindegyike 2-2 szárnnyal, s a szárnyak pedig szintén 2-2 szakasszal rendelkeztek, amelyeken belül több szekcióval és azon belül 2-3 örssel rendelkező helyőrségeket alakítottak ki. ${ }^{20}$ (I.sz. melléklet) A testület továbbra is milánói székhellyel működött, amelynek vezényleti nyelve a német volt, majd 1850-től az olasz belszolgálati és igazgatási nyelvet szintén a német nyelv váltotta fel. ${ }^{21} \mathrm{~A}$ lombardiai és dél-tiroli területeken sikeresen megszervezett és müködetett zsandárság vált a HABSBURG-birodalom egészére kiterjedő csendőrség kiindulópontjává.

A XIX. században - a Brit-szigetek kivételével — Európa valamennyi országában bevezették a csendőrség intézményét. E testület típus a korabeli rendőrségeknél gyorsabban, eredményesebben, olcsóbban és hosszú távon volt képes a polgári elvárásoknak megfelelő közrendet kialakítani és fenntartani vidéken. ${ }^{22}$

A neoabszolutizmus időszakában a Kárpát-medence területén a birodalmi belügyminisztérium, illetve a Legfőbb Rendőrhatóság irányította a közbiztonsági teendőket, így a csendőrség is a felügyelete alá tartozott. ${ }^{23}$

A neoabszolutizmust megelőzően már a reformkorban is felvetődött Magyarország főurai között egy katonailag szervezett fegyveres őrtestület felállításának a gondolata, amely érdekében 1848 márciusában már 60000 forintot össze is gyüjtöttek, viszont a tervezet csendőrség kiépítését megakadályozták az 1848-1849-es forradalom és szabadságharc eseményei. ${ }^{24}$

A birodalmi kormány — az 1849 júliusában hozott uralkodói intézkedés végrehajtása tárgyában — , 1849. VIII. 13-át követően elrendelte a birodalmi csendőrség szervezetének a kiépítését a HABSBURG-birodalom teljes területén. Az első ezredet Pozsonyban állították fel, majd 1850. I. 6-án Győrben a 2 . számú csendőr ezredet. ${ }^{25}$

1850 tavaszára a birodalmi csendőrség 16 ezred felállításával lefödte a HABSBURG-birodalom teljes területét. ${ }^{26} \mathrm{~A}$ felállított csendőr ezredek kiképzésében a lombardiai ezred tisztjei és legénysége is részt vett. A testületet 1854-ig további három ezreddel bővült, viszont 1860-ban, a meglévő 19 ezredet 10 ezredre redukálták. ${ }^{27}$ A birodalmi csendőrség 1857-ben érte el a legkiterjedtebb formáját, ekkor 19 ezredbe szervezve 18985 főnyi létszámmal összesen 2606 őrsön teljesített szolgálatot a testület. ${ }^{28}$

Az erdélyi tartományok közbiztonsági ügyeit 1850. I. 18-tól Nagyszebenből irányították. ${ }^{29}$

Az Erdélyi Udvari Kancellária és Erdély lakossága — hasonlóan Magyarország más területeihez — első ízben 1850 januárját követően ismerkedhetett meg a HABSBURG-birodalom centralizált csendőr testületével. ${ }^{30} \mathrm{~A}$ birodalmi csendőrség szolgálati nyelve a német, legénysége pedig osztrák szellemiségü volt, továbbá a tiszti kar idegen vidékről érkezett. A testület — döntően tartományonként — ezredekből állt, amelyek szárnyakra, azon belül pedig szakaszokra, a szakaszok pedig örsökre tagolódtak. ${ }^{31}$ A katonailag szervezett csendőrség, mint örtestület és a hadsereg kiegészítő részét alkotva a Csendőr Felügyelöség irányítása alá tartozott (General-Inspection), amely Bécsben müködött. $^{32}$

A Csendőr Felügyelőséget pedig a Legfelsőbb Rendőrhatóság irányította, melynek az élére Ferenc József azt a báró Johann Franz KEMPEN von Fichtenstamm altábornagyot nevezte ki meghagyva az 1849. IX. 7-én jóváhagyott csendőr felügyelöi beosztásában — aki az 1848-1849-es magyar forradalom és szabadságharcot cári csapatok segítségével leverő, majd a magyar hazafiakon véres bosszút álló Julius Jacob von HAYNAU tábornagy bizalmasa és jobbkeze volt. A birodalmi csendőrség kivételes, elit alakulatnak minősült a neoabszolutizmus rendszerén belül. Már a testület felállítását elrendelő pátens kimondta, hogy a haderőben más fegyver- és csapatnemeknél szolgáló tizedesekkel azonos állásúnak kell tekinteni a közcsendört. A testület müködési alapelveit rögzítő 1850. I. 18-án kibocsátott ideiglenes csendőr törvény pedig meghatározta, hogy a testület személyi tekintetben a hadügy, a biztonsági szolgálatellátást illetően pedig a belügyi tárca kompetenciájába tartozott. Ebből fakadóan pedig a birodalmi csendőrség felügyelöjét lényegében a két kormánytaggal egy szintre emelte és ezáltal az uralkodó közvetlen alárendeltségébe helyezte. E folyamat kicsúcsosodásaként hozta létre az uralkodó az 1852. IV. 25-ei nyílt parancsával a közvetlen alárendeltségébe helyezve a Legfelsőbb Rendőrhatóságot, amely a birodalmi csendőrség mellett — az ugyancsak centrális felépítésü és irányítású — a városok területére kiterjedő hatáskörü birodalmi rendőrségnek is a felettes irányító szervezetévé vált. ${ }^{33}$

A birodalomban a zsandárok és feletteseik elsődleges feladata - a közbiztonság felügyelete mellett - a forradalomban aktív szerepet vállalt hazafiak üldözése, a sajtó szigorú ellenőrzése, szemé- 
lyek megfigyelés volt, amely eredményességében a birodalmi rendőrség közbenjárása is közrejátszott. ${ }^{34}$

A birodalmi csendőrség kiterjesztésével párhuzamosan kiépítették az birodalmi rendőrséget is, ettől kedve külön intézményekben, egymástól elválasztva müködtek a birodalmi és a helyi rendőrségek intézményei. ${ }^{35}$

A szabadságharc előtt a városokban müködő rendőri szervezetek önkormányzati alapon müködtek. 1852. IV. 24-ét követően a birodalom városainak egészére kiterjesztették a birodalmi rendőrség szervezetét. $^{36}$

A közigazgatás feladatkörét, hatáskörét értelmezése szerint az állam alkalmazza és gyakorolja a közigazgatáson keresztül a „hatalmát, impériumát, tehát a cselekvésben olyan tényezővel rendelkezik, amely csak az államnak áll rendelkezésére és amely ezért különös lehetőségeket, müködési teret és feladatokat nyit meg és jelöl ki számára., ${ }^{37}$ A forradalmi hangulat megszünése, a belbiztonság szilárddá válása esetén tehát a rendvédelmi szervezetek tevékenységében a revolutio megelőzését szolgáló teendők kerültek elötérbe „az embereket parancsok és tilalmak kibocsátásával kötelezi a közérdeknek megfelelő magatartásra, az egyéni szabadság és magántulajdon korlátozásával is. A parancsok és tilalmak vagy általános érvényűek, vagy konkrét esetre vonatkozók." ${ }^{38}$ Ennek fényében felügyelte és ellenőrizte a birodalmi rendőrség és csendőrség a közbiztonságot, szigorúan elejét véve egy újabb forradalmi láncreakció kibontakozásának.

A 1848-1849-es magyar forradalom és szabadságharc folytatására egy utolsó kísérletre is sor került Háromszék történetében. A HABSBURG-birodalom területén felállított — a császári érdekeket előtérbe helyező - rendvédelmi szervezetek kiépítése nem tántorította el az emigrációba kényszerült magyar hazafiakat attól, hogy újabb szervezkedésbe fogjanak. Törökországban egy újabb forradalom terveit szőtték.

Az emigrációban lévő VÁRADI József társaival egyetemben a szabadságharc újrakezdését tủzte ki célul. 1851. III. 29-én találkoztak a szintén Törökországban élő KossuTH Lajossal, aki katonai lépésüket jóváhagyta. A tervezett fegyveres megmozdulás kiindulópontját Székelyföldről képzelték el. 1852 júliusában Háromszékre érkezett VÁRADI József, mint a helyi megmozdulás fő szervezője. Verbuválása során Zoltán községében 1853-ban majdnem a hatóságok kezébe került, viszont az általa képviselt céllal szimpatizálóknak köszönhetően megmenekült. A Háromszéken állomásozó katonai alakulat parancsnoka vérdíjat tüzött ki fejére, így hamarosan árulás következtében Bélafalván a hatóságok elfogták szabadcsapatának tagjaival együtt. A szervezők ellen Marosvásárhelyen, felségárulás címen pert indítottak, amelynek végeredményeként, 1854. IV. 6-án halálos ítéletet hirdettek ki VÁRADI József és BARTALIS Ferenc ellen. A kivégzésre Sepsiszentgyörgy határában került sor 1854. IV. 29-én.

Rabságuk utolsó éjszakájának helyszínét, napjainkban a város szívében található emlékfelirat és a Lábas-ház néven ismert épület őrzi. (II.sz. melléklet)

A HABSBURG-birodalom a solferinói csatában (1859. VI. 24.) - ahol mintegy 40 ezer fő vesztette életét - súlyos veszteséget szenvedett el a francia-olasz csapatoktól. ${ }^{39}$ Az HABSBURG-birodalom sebei gyógyítása céljából átalakította az addig fenntartott közbiztonsági rendszerét. A csendőrség létszámát, abból fakadóan pedig kiadásait csökkentette, továbbá pedig leállították a rendőrminisztérium müködését is. A városokban rendôr-igazgatóságokat és városi kapitányságokat állítottak fel, amelyek kiadásait a továbbiakban az önkormányzatoknak kellett viselniük. ${ }^{40}$

A 19 csendör ezredet 9 ezredbe vonták össze. A mérsékelt létszámmal továbbélő testület mellett, Magyarország területein — kivéve Erdélyt és a Horvát-Szlavóniát — visszaállították az 1848 előtt működő pandúr szervezeteket. Az állami kiadásokra ezen intézkedések jó hatással voltak, viszont annál kevésbé mondható el ez a közbiztonságra vonatkozóan. ${ }^{41}$

A testület karcsúsítása kapcsán azonban nem számolták fel az erdélyi csendőr ezredet, az erdélyi zsandárság továbbra is fennmaradt. Az erdélyi csendőr ezred hadrendi sorszáma azonban a 8.-ról a 9.re változott. ${ }^{42}$

A HABSBURG-birodalom Königrätz-i veresége nyomán (1866. VII. 3.) felerösödött a birodalmi vezetésen belül a kül- és belpolitika vezetése átértékelésének az igénye. Königrätz után világossá vált, hogy a HABSBURG vezetéssel megvalósuló és a német államokat, valamint a HABSBURG-birodalmat is magába foglaló nagy közép-európai birodalom létrehozása vágyálom marad, mivel a kisnémet egység valósul meg a poroszok vezetésével. Emellett pedig az is nyilvánvalóvá vált, hogy a birodalom erőforrásait át kell csoportosítani, mivel annak túl nagy részét foglalja el a belső elnyomásra fordított rész. Ezért tehát ki kell egyezni a magyarsággal. Ez az új felfogás és a DEÁK Ferencí-i koncepció 
találkozása eredményezte a kiegyezést. A kiegyezéssel megvalósult Erdély és Magyarország többi részének újraegyesítése, valamint a polgári magyar állam fejlődése szabad utat kapott. ${ }^{43}$

Ennek a részeként jöhetett létre az Osztrák Császárságban és a Magyar Királyságban is az önálló rendvédelmi modell. A kiegyezés ugyanis a közös ügyekbe a hadügyet, a külügyet és azok finanszírozására szolgáló pénzügyet helyezte. Ezek voltak az úgynevezett pragmatikus ügyek, amelyet a két társország, azaz az Osztrák Császárság és a Magyar Királyság közösen intézett. Megegyezés hiányában nem volt lehetséges egyik társország számára sem az önálló intézkedés, mivel ekkor a korábbi viszonyok éltek tovább. Az úgynevezett dualisztikus ügyek esetében - amely ügycsoport a kiegyezési törvényben még nem szerepelt ugyan, azonban a dualisztikus államforma müködése során kialakult (vám- és kereskedelmi szerződés, jegybank és pénzügyek, államhitel, posta, vasút, hajózás) — viszont a közös megegyezés hiányában a két társország önállóan is intézkedhetett. A kiegyezéssel tehát egy olyan dualisztikus államkonstrukció jött létre, ahol egyik fél sem mondott le a szuverenitásáról, azonban szuverenitása egy részét közösen intézte. ${ }^{44}$

A rendvédelem pedig mint a közigazgatás része a két társország belügyévé vált, amely nem tartózhatott a közös ügyek közé. Ezzel ellentétes volt, hogy Erdélyben és Horvátországban is fennmaradt — a közös haderő részeként - egy-egy csendőr ezred, amely a politikai ellenzék kedvenc vesszőparipája volt. Ennek a helyzetnek a megszüntetése érdekében TiSZA Kálmán — miután nyilvánvalóvá vált, hogy az önkormányzati rendőrségi modell a Magyar Királyságban megbukott, 1876-ban az uralkodóval és a közös haderővel folytatott tárgyalás nyomán az erdélyi és a horvátországi csendőr ezredeket a magyar kormány fennhatósága alá helyezte. A két csendőr ezred személyi állományának az átrostálása nyomán — a magyar politikai elit várakozásának megfelelően, derekasan helytálltak a közbiztonság fenntartása terén. ${ }^{45}$

Összegzésképpen megállapítható, hogy a vizsgált korban Erdély a HABSBURG hatalom szigorú ellenőrzése alatt állt. A szociális nehézségek és politikai eszmék, célok, lázadásban vagy forradalomban való kibontakozását aránylag hamar felszámolták. A HABSBURGok kiválóan tudták érvényesíteni a közigazgatási és rendvédelmi rendszerüket a hatalmuk fenntartása érdekében. A neoabszolutizmus előtti erdélyi rendvédelmi struktúra, amely lényegében az önkormányzatok hatáskörébe tartozott, az 1848-1849-es magyar forradalom és szabadságharc után már nem volt alkalmas arra, hogy a HABSBURG hatalom érdekeit szolgálja, ezért a HABSBURGok a teljes birodalomra kiterjedő hatállyal új rendvédelmi modellt hoztak létre, amelyet Erdélyben is érvényre juttattak. Ez a modell azonban egyben a magyar nemzet ellenes is volt, bár a rendet sokkal eredményesebben tartotta fenn mint a korábbi magyar önkormányzati rendvédelmi modell. A kiegyezéssel teremtődött meg annak a feltétele, hogy Erdélyben, illetve a teljes Magyar Királyságban olyan rendvédelmi modell alakulhasson ki, amely a közbiztonság fenntartása terén eredményes ugyanakkor pedig nem ellentétes a müködése a magyar érdekekkel.

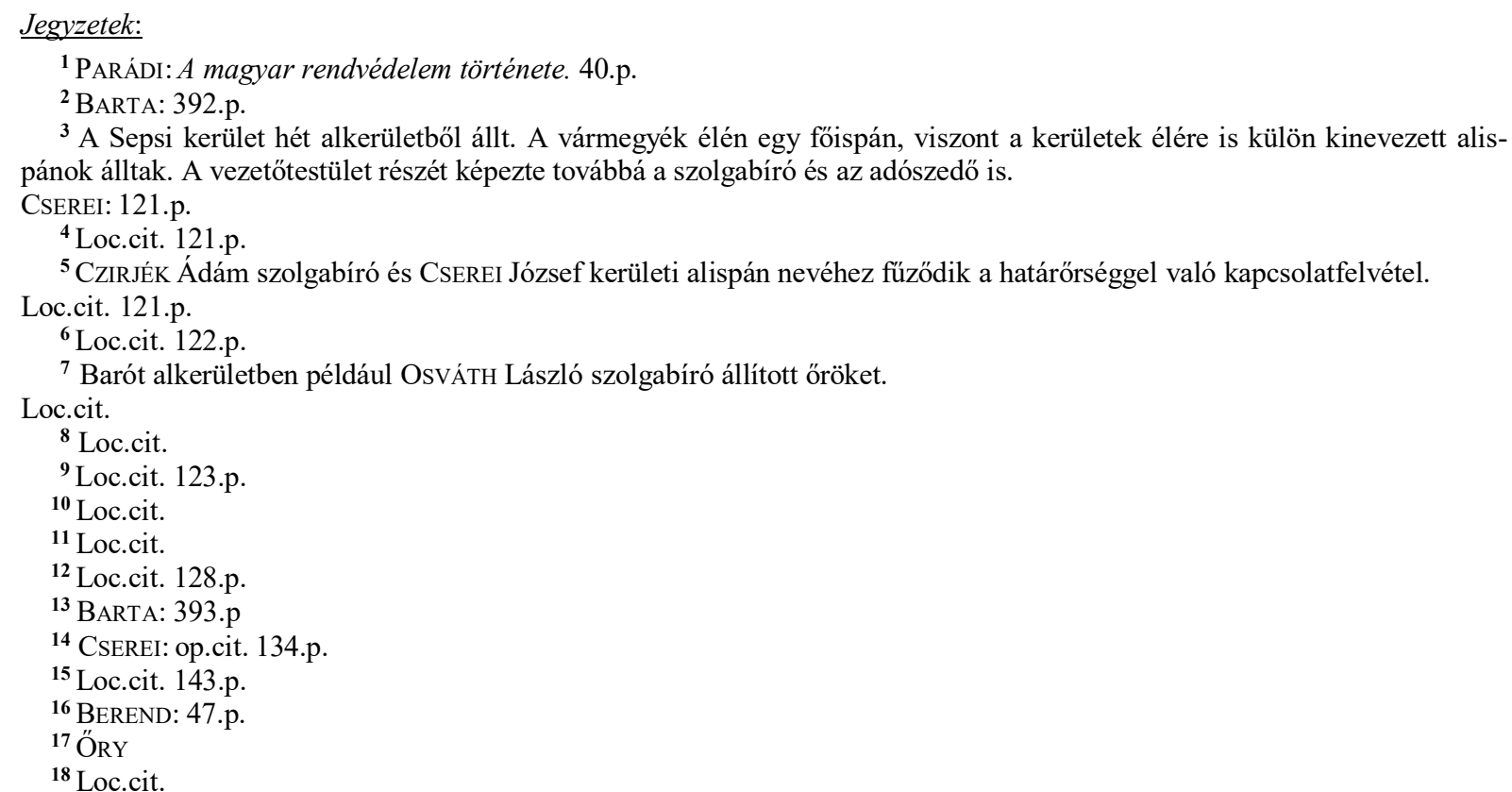


${ }^{19}$ PARÁDI: A Magyar Királyi Csendőrség. Az első magyar polgári, központositott, közbiztonsági örtestület 1881-1945.

${ }^{20}$ CSAPÓ: 11.p.

${ }^{21}$ PRESZLY: 18.p.

${ }^{22}$ PARÁDI: A Magyar Királyi Csendőrség. Az elsö magyar polgári, központositott, közbiztonsági örtestület 1881-1945. op.cit. 30.p.

23 - MEZNERICS - TORDAY: 57.p.

- 1849. III. 4-én az Olmütz-i összbirodalmi alkotmány 36. §-a már rögzítette, hogy „A birodalom belső biztonságának az őrzése birodalmi ügy.” (Reichsgesetzblatt Nr. 150/1849.)

- A birodalmi csendőrség felállítását uralkodói intézkedés rendelte el 1849. VII. 8-án (Reichsgesetzblatt Nr. 272/1849.)

ZACHAR: Tradíció és folyamatosság az osztrák rendvédelmi szerveknél. 69.p.

- A neoabszolutizmus rendszerében 1852-ben vezették be a Legfelsőbb Rendőrhatóság intézményét, melyet 1859-től a rendőrminisztérium váltott fel.

ZACHAR: Az Osztrák-Magyar Monarchia örökös tartományainak rendvédelmi testületei. 24.p.

- Az uralkodó a birodalmi csendőrség múködését az 1850. I. 18-án kibocsátott ideiglenes csendőr törvénnyel szabályozta.

ZACHAR: Fejezetek az osztrák csendőrség történetéből 1849-1918. 105.p.

${ }^{24}$ PRESZLY: op.cit. 19.p.

${ }^{25}$ CSAPÓ: op.cit. 11.p.

${ }^{26}$ A 16 csendőr ezred székhelyei voltak: 1. Bécs, 2. Prága, 3. Brünn, 4. Lemberg, 5. Pest, 6. Győr, 7. Nagyvárad, 8. Nagyszeben, 9. Temesvár, 10. Zágráb, 11. Laibach, 12. Grác, 13. Innsbruck, 14. Mailand, 15. Padua, 16. Zára.

HESZTERA ; ZACHAR: Fejezetek az osztrák csendőrség történetéből 1849-1918. op.cit. 107.p.

${ }^{27}$ PRESZLY: op.cit. 19.p.

${ }^{28}$ CSAPÓ: op.cit. 11.p.

${ }^{29}$ Loc.cit.

${ }^{30}$ REKTOR: 68.p.

${ }^{31}$ Loc.cit. 69.p.

${ }^{32}$ MEZNERICS - TORDAY: op.cit._70.p.

${ }^{33}$ ZACHAR: Fejezetek az osztrák csendőrség történetéből 1849-1918. op.cit. 105-106.p.

${ }^{34}$ PARÁDI: A Magyar Királyi Csendörség. Az elsö magyar polgári, központositott, közbiztonsági örtestület 1881-1945. op.cit. 31.p.

${ }^{35}$ CSAPÓ: op.cit. 11.p.

${ }^{36}$ Erdélyen belül Nagyszebenben, Kolozsváron és Brassóban állítottak fel császári és királyi rendőr igazgatóságokat.

${ }^{37}$ MAGYARY: 39.p.

${ }^{38}$ Loc.cit. 568.p.

${ }^{39}$ ORMOS - MAJOROS: 121.p.

${ }^{40}$ CSAPÓ: op.cit. 12.p.

${ }^{41}$ PARÁDI: A Magyar Királyi Csendőrség. Az első magyar polgári, központositott, közbiztonsági örtestület 1881-1945. op.cit. 32.p.

${ }^{42}$ REKTOR: op.cit. 69.p.

${ }^{43}$ GALÁNTAI: 43-86.p.

${ }^{44}$ Loc.cit. 87-120.p. ; 1867/XII.tc.

45 PARÁDI: A Magyar Királyi Csendörség. Az elsö magyar polgári, központositott, közbiztonsági örtestület 1881-1945. op.cit. 32-39.p.

\section{Jegyzetekben alkalmazott röviditések:}

\section{MONOGRÁFIÁK, KISMONOGRÁFIÁK ÉS HASONLÓ JELLEGŰ KÖTETEK}

\section{BARTA}

(2.;13.;)

BEREND

(16.;)

CSAPÓ

$(20 . ; 25 . ; 28 . ; 29 . ; 35 . ; 40 . ;)$

\section{GALÁNTAI}

(43.,44.;)

MAGYARY

(37.;38.;)

MEZNERICS - TORDAY

(23.;32.;)

ORMOS - MAJOROS

(39.;)
BARTA Gábor et al. (szerk.): Erdély rövid története. Budapest, 1989, Akadémiai Kiadó. 672 p. HU-ISBN 9630555433.

BEREND T. Iván: Kisiklott történelem. Közép- és Kelet-Európa a hosszú 19. században. Budapest - Dabas, 2003, Magyar Tudományos Akadémia Történettudományi Intézete - História. 277 p. HU-ISBN 963831284 X. /História könyvtár, Monográfiák, 19./ HU-ISSN 1217-212X.

CsAPó Csaba: A Magyar Királyi Csendörség története 1881-1914. Pécs, 1999, Pro Pannónia Kiadói Alapítvány. 186 p. HU-ISBN 9639079405. /Pannónia Könyvek./ HU-ISSN 0237-4277.

- Galántai József: A Habsburg-monarchia alkonya. Osztrák-magyar dualizmus 1867-1918. Budapest, 1985, Kossuth. 387 p. HU-ISBN 9630925893.

MAGYARY Zoltán: Magyar közigazgatás. A közigazgatás szerepe a XX. sz. államában. A magyar közigazgatás szervezete, müködése és jogi rendje. Budapest, 1942, Magyar Királyi Egyetemi nyomda. 676 p.

MEZNERICs Iván - TORDAY Lajos: A magyar közigazgatás szervei, 1867-1937. Budapest, 1937, Székesfőváros. 447 p. /Magyar Közigazgatás-tudományi Intézet, 21./

ORMOS Mária - MAJOROS István: Európa a nemzetközi küzdőtéren. Budapest, 2003, Osiris Kiadó. 504 p. HU-ISBN 9789633895016. 
PARÁDI: A magyar rendvédelem történe- te.

$(1 . ;)$

PARÁDI: A Magyar Királyi Csendőrség. Az elsö magyar polgári, központositott, közbiztonsági örtestület 1881-1945.

(19.;22.;34.;41.;45.;)

PRESZLY

(21.;24.;27.;)

REKTOR

$(30 . ; 31 . ; 42 . ;)$

\section{TANULMÁNYOK}

CSEREI

(3.;4.;5.;6.;7.;8.;9.;10.;11.;12.;14.;15.;)

HESZTERA

(26.;)

ÖRY

(17.;18.;)

ZACHAR: Az Osztrák-Magyar Monarchia örökös tartományainak rendvédelmi testületei.

(23.;)

ZACHAR: Tradíció és folyamatosság az osztrák rendvédelmi szervezeteknél. (23.;)

ZACHAR: Fejezetek az osztrák csendőrség történetéből 1849-1918.

(23.;26.;33.;)

\section{JOGSZABÁLYOK}

1867/XII.tc.

(44.;)
PARÁDI József et. al. (szerk.): A magyar rendvédelem története. Budapest, 1996², Osiris. 367 p. HU-ISBN 9630479583.

PARÁDI József: A Magyar Királyi Csendőrség. Az elsö magyar polgári, központositott, közbiztonsági örtestület 1881-1945. Budapest, 2012, Szemere Bertalan Magyar Rendvédelem-történeti Tudományos Társaság. 281 p. HU-ISBN 978963084794 0. /A magyar rendvédelem-történet öröksége, 2./ HU-ISSN 2062-8447.

PRESZLY Lóránd: A Magyar Királyi Csendőrség története 1881-1919. Budapest, 1920, Honvédelmi Sajtóvállalat. 142 p.

RekTor Béla: A Magyar Királyi Csendörség oknyomozó története. Cleveland, Ohio, USA, 1980, Árpád Könyvkiadó Vállalat. 552 p. USA-ISBN 0934214018

CSEREI Zoltán: Társadalmi feszültségek és villongások Háromszéken a XVIII. század utolsó harmadában. 120-145.p. In EGYED Ákos - MAGYARI András et al. (szerk.): A székelység története a 17-19. században. Csíkszereda, 2001, Pallas-Akadémia Könyvkiadó. 360 p. RO-ISBN 9738079411. /Bibliotheca Transsylvanica./

HESZTERA Franz: Die Kommandostrukturen der Gendarmerie von 1850 bis 1993. [A csendörség parancsnoksági rendszere 1850-1993 között.] Rendvédelem-történeti Füzetek (Acta Historiae Praesidii Or-dinis), IV. évf. (1994) 5.sz. 18-35.p. HU-ISSN 1216-6774. A tanulmány korábbi változata 1993. szeptember 21-én, Budapesten hangzott el a Szemere Bertalan Magyar Rendvédelem-történeti Tudományos Társaság által szervezett rendvédelem-történeti tudományos konferencia-sorozatnak. „Háború, forradalom, trianon” című V. konferenciáján. A publikált tanulmány az előadás javított, bővített és átdolgozott változata.

ÖRY Károly: A Maréchaussée-tól a Gendarmerie Nationale-ig. A Francia Csendőrség történeti előzményei. Rendvédelem-történeti Füzetek (Acta Historiae Praesidii Ordinis), VII.évf. (1997) 8.sz. 75-77.p. HU-ISSN 12166774. A tanulmány korábbi változata 1996. október 29-én Budapesten hangzott el a Szemere Bertalan Magyar Rendvédelem-történeti Tudományos Társaság által szervezett rendvédelem-történeti tudományos konferencia-sorozatnak „A napóleoni közbiztonsági örtestület útja Párizstól - Itálián és Ausztrián keresztül - Budapestig” címü VIII. konferenciáján. A publikált tanulmány az előadás javított, bővített és átdolgozott változata.

ZACHAR József: Az Osztrák-Magyar Monarchia örökös tartományainak rendvédelmi testületei. Rendvédelem-történeti Füzetek (Acta Historiae Praesidii Ordinis), HU-ISSN 1216-6774. I.évf. (1991) 1.sz. 17-29.p. HUISSN 1216-6774. A tanulmány korábbi változata 1990. április 24-én Budapesten hangzott el a Szemere Bertalan Magyar Rendvédelem-történeti Tudományos Társaság által szervezett rendvédelem-történeti tudományos konferenciasorozatnak „A magyar rendvédelmi testületek és az önkormányzati szervek kapcsolata 1848-1945"címü I. konferenciáján. A publikált tanulmány az előadás javított, bővített és átdolgozott változata.

ZACHAR József: Tradíció és folyamatosság az osztrák rendvédelmi szervezeteknél. Rendvédelem-történeti Füzetek (Acta Historiae Preasidii Ordinis), HU-ISSN 1216-6774. II.évf. (1992) 3. sz. 65-74. p. HU-ISSN 1216-6774. A tanulmány korábbi változata 1991. november 19.-én Budapesten hangzott el a Szemere Bertalan Magyar Rendvédelem-történeti Tudományos Társaság által szervezett rendvédelem-történeti tudományos konferencia-sorozatnak „Tradíció és korszerüség” című III. konferenciáján. A publikált tanulmány az előadás javított, bővített és átdolgozott változata.

ZACHAR József: Fejezetek az osztrák csendőrség történetéből 1849-1918. Rendvédelem-történeti Füzetek (Acta Historiae Praesidii Ordinis VII.évf. (1997) 8.sz. 105-109.p. HU-ISSN 1216-6774. A tanulmány korábbi változata 1996. október 29-én, hangzott el, Budapesten a Szemere Bertalan Magyar Rendvédelem-történeti Tudományos Társaság által szervezett magyar rendvédelem-történeti tudományos konferencia-sorozatnak „A napóleoni közbiztonsági örtestület útja Párizstól — Itálián és Ausztrián keresztül - Budapestig" címü VIII. konferenciáján. A publikált tanulmány az előadás javított, bővített és átdolgozott változata.

1867/XII.tc. a Magyar Korona országai és az Ö Felsége uralkodása alatt álló többi országok között fennforgó közös érdekü viszonyokról, s ezek elintézésének módjáról. 


\section{Mellékletek jegyzéke:}

I.sz. melléklet

A lombardiai csendőr ezred szervezeti felépítése.

II.sz. melléklet

A sepsiszentgyörgyi Lábas Ház.

\section{A lombardiai csendôr ezred szervezeti felépitése.}

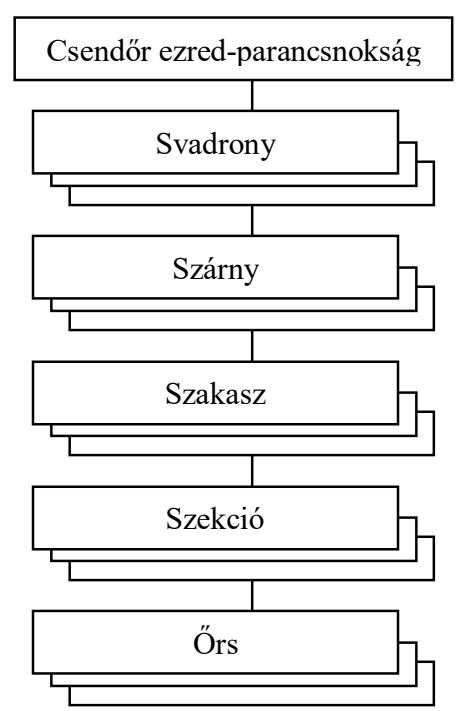

Forrás ! PRESZLy Lóránd: A Magyar Királyi Csendőrség története 1881-1919. Budapest, 1920, Honvédelmi Sajtóvállalat. 142 p.

\section{A sepsiszentgyörgyi Lábas Ház.}

II.sz. melléklet

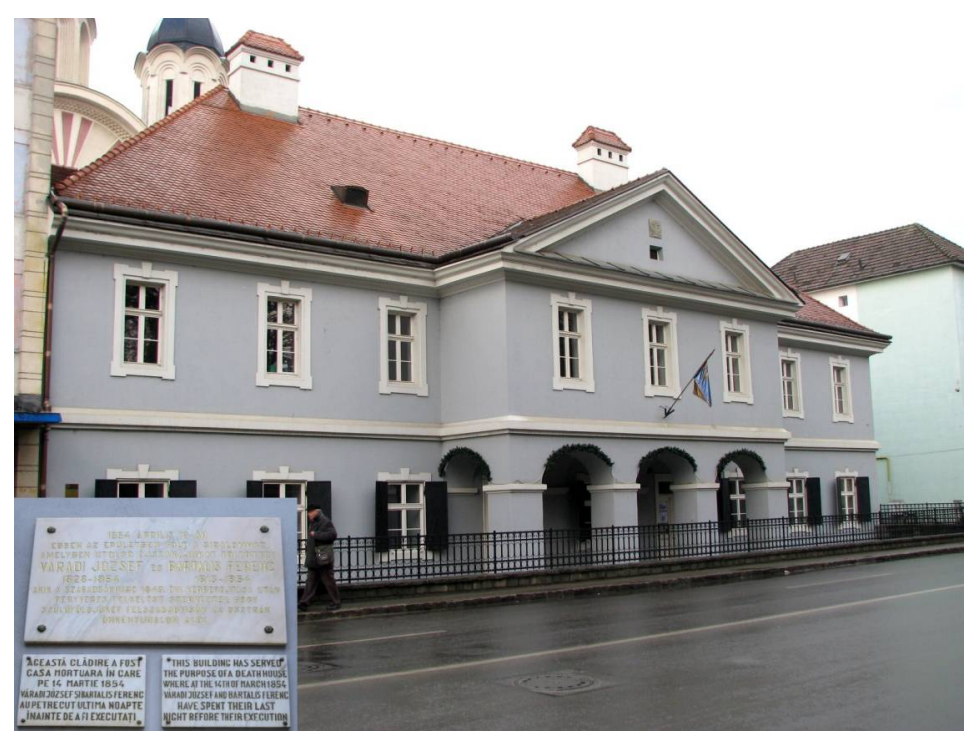

Forrás ! A szerző magán fotógyüjteménye. 